\title{
AN OUTBREAK OF CONTAGIOUS AGALACTIA IN SHEEP
}

\author{
G. D. KUMARI* AND R. N. R. PUSHPA \\ Department of Veterinary Microbiology \\ NTR College of Veterinary Sciences, Gannavarm, Krishna 521102 \\ Sri Venkateswara Veterinary University, Tirupati, Andhra Pradesh, India
}

\begin{abstract}
The present study was aimed for the confirmatory diagnosis of contagious agalactia syndrome in sheep herds belonging to Ibrahimpatnam and Mylavaram mandals of Krishna district, Andhra Pradesh. A total of 37 clinical samples were collected from the affected sheep with a history of keratoconjuctivitis, corneal opacity, arthritis, anorexia and mastitis without any reports of mortality. The symptoms of the affected sheep were preliminarily suggestive of Mycoplasmal infections. An attempt was made for confirming the organism based on genotypic characterization by employing molecular based technique, polymerase chain reaction using mycoplasma group specific primers for a quick diagnosis. All the 37 samples were processed for DNA extraction by employing high salt DNA extraction method and phenol chloroform method. Amplification of the mycoplasma gene produced an amplicon product size of 270bp indicating $100 \%$ positivity to Mycoplasma infection among the herd.
\end{abstract}

Key words: Keratoconjunctivitis, Mycoplasma, Polymerase chain reaction, Small ruminants, Tetracyclines

Mycoplasmas are the smallest selfreplicating bacteria capable of cell-free existence. They are more closely related to the Gram-positive bacterial group. It is an atypical bacterium belonging to the class of Mollicutes and is devoid of cell wall around their cell membrane. In small ruminants, these bacterial infections are associated with predisposing factors like primitive herding practices, inefficiency of antimicrobial therapies and adoption of very few prophylactic measures (Gil et al., 1999). Mycoplasma infections affect primarily the mammary glands, joints and eyes causing severe infections in small ruminants that result in economic loss to the shepherds due to high morbidity rather than mortality (Lambert, 1987). The incubation period of the mycoplasma infection in goats and sheep is one to eight

\footnotetext{
"Corresponding Author
} 
weeks (Azevedo et al., 2006). In some animals, the clinical symptoms include fever, anorexia, lethargy and aversion to follow the herd (Kizil and Ozdemir, 2006). Mycoplasma infections are present all over the continents especially in Europe, Asia and Africa, mainly in the countries around the Mediterranean (Azevedo et al., 2006; Egwu et al., 2001; Fasanya et al., 1987; Real et al., 1994; Singh et al., 2004). The mycoplasma infections localize in the mammary glands, eye, joints, lungs and cause local inflammation in the respective area. Pneumonia and abortions are characteristic of chronic mycoplasma infections in small ruminants. In the present study, few sheep were investigated for mycoplasmal infections as they were showing symptoms of corneal opacity, arthritis, anorexia and mastitis.

The affected sheep $(n=37)$ were showing clinical signs like keratoconjunctivitis, corneal opacity, arthritis, anorexia and clots in milk without any reports of mortality. A total of thirty seven samples pertaining to different specimens were collected from Ibrahimpatnam and Mylavaram mandal of Krishna district, Andhra Pradesh and brought to NTR CVSc., Gannavaram in transport medium like phosphate buffer saline placed on ice. The list of clinical samples is listed in Table 1.
The DNA was extracted from all the 37 samples by employing two methods, viz. high salt method and phenol-chloroform method.

The procedure of Aravindakshan et al. (1997) was followed. Briefly, $1 \mathrm{~mL}$ culture was centrifuged at $5000 \times g$ for $10 \mathrm{~min}$ at $4^{\circ} \mathrm{C}$. The pellets were then re-suspended in $1 \mathrm{~mL}$ of PBS and mixed properly and later centrifuged at $5000 \times g 10 \mathrm{~min}$ at $4^{\circ} \mathrm{C}$. The pellets were then re-suspended in $100 \mu \mathrm{L}$ of TKM-I solution, a low salt buffer [TrisHCl $(10 \mathrm{mM}) \quad \mathrm{pH} \quad 7.6, \quad \mathrm{KCl} \quad(10 \mathrm{mM})$, $\left.\mathrm{MgCl}_{2}(10 \mathrm{mM}), \operatorname{EDTA}(2 \mathrm{mM})\right]$ and centrifuged at $5000 \times g 10 \mathrm{~min}$ at $4^{\circ} \mathrm{C}$. The pellet was re-suspended in $100 \mu \mathrm{L}$ of TKMII solution, a high salt buffer [TrisHCl (10mM) pH 7.6, $\mathrm{KCl}(10 \mathrm{mM}), \mathrm{MgCl}_{2}$ $(10 \mathrm{mM}), \operatorname{EDTA}(2 \mathrm{mM}) \mathrm{NaCl}(0.4 \mathrm{M})]$ and incubated for $15 \mathrm{~min}$ at $37^{\circ} \mathrm{C}$. To the above suspension $50 \mu \mathrm{L}$ of SDS-Sodium Dodecyl Sulphate, $10 \%$ plus $250 \mu \mathrm{L}$ of $6 \mathrm{M} \mathrm{NaCl}$ was added and mixed thoroughly and centrifuged at $10,000 \times g$ for $5 \mathrm{~min}$ at $4^{\circ} \mathrm{C}$. The supernatant was collected into an eppendorf tube and absolute alcohol was added to double the quantity of supernatant obtained and centrifuged at $10,000 \times g$ for $5 \mathrm{~min}$ at $4^{\circ} \mathrm{C}$. The pellet was re-suspended in $75 \%$ ethyl alcohol and centrifuged at $10,000 \times g$ for $5 \mathrm{~min}$ at $4^{\circ} \mathrm{C}$. The process

Table 1. List of clinical samples

\begin{tabular}{lccccc}
\hline Species & Milk & Joint exudates & Nasal swabs & Corneal swabs & Total \\
\hline Ovine & 13 & 9 & 6 & 9 & 37 \\
\hline
\end{tabular}


was done twice to remove any impurity. Finally, the pellet was dissolved in $50 \mu \mathrm{L}$ of Milli Q water and stored at $-80^{\circ} \mathrm{C}$ until further use.

The DNA samples for PCR were prepared by phenol-chloroform method (Azevedo et al., 2006). One milliliter culture was centrifuged at $20,000 \times g$ for $20 \mathrm{~min}$ at $4^{\circ} \mathrm{C}$. The pellets were then re-suspended in 400 $\mu \mathrm{L}$ of lysis buffer [Dextrose-EDTA buffer, $\mathrm{pH} 8.4$, plus $30 \mu \mathrm{L}$ of proteinase $\mathrm{K}(240$ $\mu \mathrm{g} / \mathrm{mL}$ ) plus $30 \mu \mathrm{L}$ of SDS-Sodium dodecyl sulphate, 10\%], and incubated for $30 \mathrm{~min}$ at $50^{\circ} \mathrm{C}$. After fast cooling, it was carried out double extraction with $500 \mu \mathrm{L}$ of phenol ( $\mathrm{pH}$ 7.8) followed by one extraction with $500 \mu \mathrm{L}$ of chloroform and addition of 100 $\mu \mathrm{L}$ of ethanol to the final aqueous phase and stored overnight at $-20^{\circ} \mathrm{C}$. Samples were centrifuged at $20,000 \times g$ for $10 \mathrm{~min}$ at $4^{\circ} \mathrm{C}$ and the pellets were re-suspended in $100 \mu \mathrm{L}$ TE buffer $(10 \mathrm{mM}$ Tris-HCl, $1 \mathrm{mM}$ EDTA, $\mathrm{pH} 8.0$ ) and placed in $-80^{\circ} \mathrm{C}$ until further use.

The nucleotide sequence of primers used in the genus specific PCR assay are as follows. Forward primers 5' GGGAGCAAACAGGATTAGATACCCT3'; and Reverse primers 5'TGCACCATCTGTCACTCTGTTAACCTC3' (Ossewaarde et al., 1996; Timenetsky et al., 2006). The PCR was carried out as described by Azevedo et al. (2006) with slight modifications.

The PCR reaction was conducted using thermocycler (Eppendorf PTC-100, MJ Research). The reaction volume was $20 \mu \mathrm{L}$, with $3 \mu \mathrm{L}$ of Milli Q water, $1 \mu \mathrm{L}(20 \mathrm{pm} /$ $\mathrm{mL}$ concentration) of each forward and

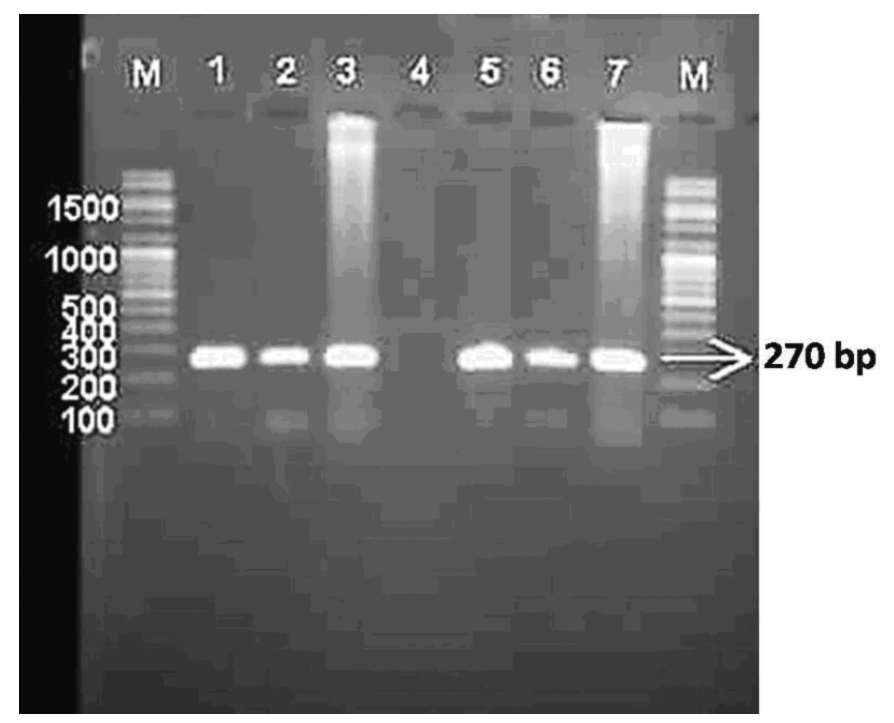

Fig. 1. An amplicon size of $270 \mathrm{bp}$ produced from the DNA extracted by high salt method $(1,2,3)$ and phenol chloroform method $(5,6,7)$ by representative samples 
reverse primer, $5 \mu \mathrm{L}$ DNA extracts. The PCR was performed by initial denaturation at $94^{\circ} \mathrm{C}$ for $5 \mathrm{~min}$, followed by 35 cycles of denaturation at $94^{\circ} \mathrm{C}$ for $30 \mathrm{sec}$, annealing at $55^{\circ} \mathrm{C}$ for $30 \mathrm{sec}$, extension at $72^{\circ} \mathrm{C}$ for $1 \mathrm{~min}$, and final extension at $72^{\circ} \mathrm{C}$ for $4 \mathrm{~min}$. The PCR product was analysed using $1.5 \%$ agarose gel. Bands were run and analysed on $2 \%$ agarose stained with ethidium bromide $(0.5 \mathrm{pg} / \mathrm{mL})$ and visualized under ultra-violet light in a Gel Doc (Bio Rad, US). The yield of DNA extracted from high salt and phenol chloroform method was varying from $80-220 \mathrm{ng} / \mu \mathrm{L}$ concentration. An amplicon size of $270 \mathrm{bp}$ was produced with the Mycoplasma group specific primers in all the 37 clinical samples indicating that the animals were succumbed to contagious agalactia syndrome.

Mycoplasma agalactiae is one of the predominant etiological factors responsible for contagious agalactia syndrome. However, other species like $M$. capricolum subsp. capricolum, $M$. putrefaciens, $M$. mycoides subsp. capri or M. mycoides subsp. mycoides large colony (LC) type can also cause this disease. With an aim of confirming the contagious agalactia syndrome in the affected sheep herd, the samples were processed for DNA extraction and subjected for the highly specific molecular technique i.e. polymerase chain reaction (Lambert, 1987). The Genus specific primers for Mycoplasma produced a PCR product size of $270 \mathrm{bp}$ from all the clinical samples indicating that all the sheep were affected and confirming that the organism for the disease is Mycoplasma. Earlier, similar results were reported by Ossewaarde et al. (1996) and Timenetsky et al. (2006). Mycoplasma is responsible for severe economic loss in livestock. Nonetheless, it is one of the most neglected diseases. Mycoplasma is highly resistant to the room temperature, thus supporting its rapid spread of the infection among the flock (Kumar et al., 2014). The high morbidity of the entire flock results in severe economic looses thus a quicker diagnosis is essential. Isolation of the mycoplasmal organisms was not carried out in the laboratory as these are very fast contaminating organisms and it is also difficult to differentiate on morphological and biochemical tests. Many tests have been employed for the diagnosis of Mycoplasmal organisms of which PCR is one of the most sensitive and faster tests to confirm. PCR can detect the organism even after storage of the samples at $-20^{\circ} \mathrm{C}$ for 24 months (Tola et al., 1996; Tola et al., 1997).

Most of the diseases in small ruminants are mainly due to Mycoplasmal infections that contribute to nearly $90 \%$ in causing contagious agalactia syndrome (VerbisckBucker et al., 2008). The infected sheep were treated with tetracyclines $(2.5 \mathrm{mg} / \mathrm{kg}$ body weight) for a period of 5 days. The prognosis was good after administration of the drugs and affected sheep recovered slowly back to normalcy. 
In conclusion, contagious agalactia can be controlled on following good hygienic precautions and avoiding the predisposing factors to a lesser extent. Segregation, quarantine procedures, healthy sanitary conditions like removal of bedding materials, disposing of left over feed and disinfection of the premises may contribute

\section{REFERENCES}

Aravindakshan TV, Nainar AM and Nachimuthu K, 1997. High salt method: a simple and rapid procedure for isolation of genomic DNA from buffalo (Bubalus bubalis) white blood cells. Indian J Exp Biol, 35(8): 903-905

Azevedo EO, Alcântara MD, Nascimento ER, Tabosa IM, Barreto ML et al., 2006. Contagious agalactia by Mycoplasma agalactiae in small ruminants in Brazil: first report. Brazl J Microbiol, 37(4): 576-581

Egwu GO, Ameh JA, Aliyu MM and Mohammed FD, 2001. Caprine mycoplasmal mastitis in Nigeria. Small Ruminant Res, 39(1): 87-91

Fasanya OO, Adegboye DS, Molokwu EC and Dim NI, 1987. Microbiology of the genitalia of nulliparous and postpartum Savanna Brown goats. Vet Res Com, 11: 191-198

Gil MC, de Mendoza MH, Rey J, Alonso JM, Poveda JB et al., 1999. Aetiology of caprine contagious agalactia syndrome in extra madura, Spain Vet Rec, 144(1): 2425 for the healthy status of the sheep affected with mycoplasmal infections.

\section{ACKNOWLEDGEMENTS}

The authors are thankful to the Associate Dean, NTR College of Veterinary Science, Gannavarm, Sri Venkateswara Veterinary University, Tirupati for providing the facilities to pursue this work.

Kizil O and Ozdemir H, 2006. Clinical, haematological and biochemical studies in goats naturally infected with Mycoplasma agalactiae. Bull Vet Inst Pulawy, 50(3): 325-328

Kumar A, Rahal A, Chakraborty S, Verma AK and Dhama K, 2014. Mycoplasma agalactiae, an etiological agent of contagious agalactia in small ruminants: a review. Vet Med Int, http://dx.doi.org/ $10.1155 / 2014 / 286752$

Lambert M, 1987. Contagious agalactia of sheep and goats. Rev Sci Tech OIE, 6: 699-711

Ossewaarde JM, De Vries A, Bestebroer T and Angulo AF, 1996. Application of a Mycoplasma group-specific PCR for monitoring decontamination of Mycoplasma-infected Chlamydia sp. strains. Appl Environ Microbial, 162(2): 328-331

Real F, Waelchli RO, Muller C, Hassig M and Rusch P et al., 1994. Caprine contagious agalactiae caused by Mycoplasma 
agalactiae in the Canary Islands. Vet Rec, 135:15-16

Singh VP, Srivastava NC, Kumar M, Sunder MJ and Varshney JP, 2004. Isolation and characterisation of an Indian strain of Mycoplasma mycoides subsp. mycoides type LC from a case of caprine arthritis. Comp Immunol Microbiol Infect Dis, 4(27): 273-284

Timenetsky J, Santos LM, Buzinhani M and Mettifogo E, 2006. Detection of multiple mycoplasma infection in cell cultures by PCR. Brazl J Med Biol Res, 39(7): 907914

Tola S, Angioi A, Rocchigiani AM, Idini G, Manunta D et al., 1997. Detection of
Mycoplasma agalactiae in sheep milk samples by polymerase chain reaction. Vet Microbio, 54(1): 17-22

Tola S, Idini G, Manunta D, Galleri G, Angioi A et al., 1996. Rapid and specific detection of Mycoplasma agalactiae by polymerase chain reaction. Vet Microbiol, 51(1-2): 77-84

Verbisck-Bucker G, González-Candela M, Galián J, Cubero-Pablo MJ, MartínAtance P et al., 2008. Epidemiology of Mycoplasma agalactiae infection in freeranging Spanish ibex (Capra pyrenaica) in Andalusia, southern Spain. J Wildl Dis, 44(2): 369-380 